\title{
Proposed Model for Social Capital Relationship with Online Purchase Decision in Social Network
}

\author{
Adhi Prasetio \\ Program Doktor Ilmu Manajemen \\ Universitas Pendidikan Indonesia \\ Bandung, Indonesia \\ Fakultas Ekonomi \& Bisnis \\ Universitas Telkom \\ Bandung, Indonesia \\ adhipras@telkomuniversity.ac.id
}

\author{
Vanessa Gaffar \\ Program Doktor Ilmu Manajemen \\ Universitas Pendidikan Indonesia \\ Bandung, Indonesia
}

\begin{abstract}
This study aims to propose a model for online consumer behavior within social networking site. Previous studies have tried to offer models to explain social network user's behavior regarding to purchase decision and eWOM. But so far none has tried to relate what could triggered eWOM and their relationship with purchase decision in a social network site. This study is qualitative descriptive analysis technique through the study of literature. The result of this study propose a more comprehensive model for online purchase decision within a social networking site that include social capital, eWOM, online purchase intention and online purchase decision.
\end{abstract}

Keywords - Social Networking Site; Online Purchase Decision; Online Purchase Intention; eWOM; Social Capital.

\section{INTRODUCTION}

Online retail has become an important channel and business model for many companies [1]. A research in India mentioned that huge internet base will have direct impact to online retail business [2]. Online purchase process is affected by online activities. Recent study showed that online activities is dominated by social networking [3], shifting from previously browsing activities.

Social network is a part of social media and also known as Web 2.0 service [4]. Social media allows their users to create their own web pages, create, share, and edit their own content. Social network (like Facebook and Google+) is the most popular social media form [5].

Purchase decision is the main focus of marketing efforts [6]. By understanding the reason why someone purchase something, a marketer will be able to decide proper marketing stimuli to encourage purchase. Many retailers failed to maintain profitable business due to unstable online buyer characteristics. Most of them don't trust online retailers [7]. Marketers need to understand online user's preference and mindset such as their purchase intention [2][8] since it's a strong predictor for online purchase decision [9] [10].

Internet buyer is different with offline buyer. Internet users begin and control their contact with marketing stimuli, unlike relatively passive offline buyer [6]. As an example, online marketing targets people who actively choose which web site that they will visit and what kind of marketing information that they will accept about intended product and in what condition.

The shift of online activities to social network usage brings even bigger transformation on how online marketing works. Social network force marketers to focus on social characteristics in their online marketing activities and affect online consumer behavior. Marketers have to develop internet and social network usage to interact with consumer and became part of their conversation and life, despite applying one way communication in traditional marketing [6]. This new development makes marketers become more and more rely on Word of Mouth (WOM) as part of their marketing program [11].

Study showed that sometimes positive WOM could exist naturally with small promotion effort, but also could be managed and facilitated [12]. Electronic mediated WOM is called electronic Word of Mouth (eWOM). This term refers to any statement about product, service, brand or company shared by consumers through the Internet (e.g. web site, social network, instant messages, news feeds) [14]. Various small and middle size company in US already utilized social media in their campaign. Southern Jewlz experience doubled sales since using Facebook, Twitter and e-commerce software actively [13]. This is also happens in developing country like Indonesia. Many popular brand have their own Facebook fan page like Batik Indonesia, Yamaha, Blackberry, and Chocolatos. All those brands bring strong local interaction and maintain good interaction with their followers [15].

Conversation around specific product could happen in social network. This conversation can be among social network users or in a managed Facebook fan page. This interaction is a form of electronic word of mouth that could trigger user's intention to purchase a product or service. Once their purchase intention is triggered, these potential buyer can be directed to special web page with relevant product information where the real transaction occurs. 
Previous studies have tried to offer models to explain social network user's behavior regarding to purchase decision and eWOM. But so far none has tried to relate what could triggered eWOM and their relationship with purchase decision in a social network site. Those phenomenon and previous study results indicate the need for a model to understand what caused purchase decision in social network especially regarding to electronic word of mouth.

\section{LITERATURE REVIEW}

\section{A. Social Capital}

Bordieu and Coleman are two theoretical scientist that considered to be the conceptor of modern social capital concept, since they offer the social capital term systematically [16] [17]. Although they wrote down their articles almost at the same time, but they have different point of view. Bordieu based his thought on capital theory, and Coleman used Rational Choice Theory as his approach to define social capital concept [17].

Social capital is value that someone can have through relationship like family membership, ethnic association, and group sharing. This social relationship could lead to job, loan, important information, and investment opportunity. Bordieu define social capital as "The aggregate of the actual or potential resources which are linked to possession of a durable network of more or less institutionalized relationships of mutual acquaintance and recognition" [18].

Another approach to define social capital is offered by Coleman. Coleman tried to explain social capital concept by stating that a person will take rational action as starting point, although he refused extreme individualistic premise that usually camo with it [19]. Coleman defined social capital as "A variety of entities with two elements in common: They all consist of some aspect of social structures, and they facilitate certain action of actors - whether persons or corporate actorswithin the structure" [19].

The following researchers have various definition regarding social capital [20] [21] [22]. Nevertheless, they have something in common that social capital premise believe that social network has value. Nahapiet and Ghoshal saw social capital from more comprehensive point of view and includes external and internal linkage [23]. They tried to combine various existing social capital concept, including those from Bordieu and Coleman [24] and define social capital as

"The sum of the actual and potential resources embedded within, available through, and derived from the network of relationships possessed by an individual or social unit". Social capital thus comprises both the network and the assets that may be mobilized through that network [24].

Social capital definition used in this study is the one used by Nahapiet \& Ghoshal. That definition is considered comprehensive and could represent various social network characteristics. Previous study regarding social capital in social network especially related with eWOM like [25] [26] appears to use social capital definition offered by Nahapiet \& Ghoshal. Since social network is a place for social interaction where people could gain relationship with other and social capital as well, so we could propose social capital as the antecedent of eWOM especially in a social network.

\section{B. Electronic Word of Mouth}

Kotler mentioned that a company could allocate its marketing budget for marketing communication. This marketing communication can be categorized into 8 main modal called marketing communication mix namely advertising, sales promotion, public relations and publicity, events and experiences, direct marketing, interactive marketing, word-of-mouth marketing, and the sales force [27].

Kotler explain that Word of Mouth has characteristics as follows [27]:

1. Influential, since people trust other people they know and respect, then WOM could potentially influencing.

2. Personal, WOM usually exist in dialog that show close relationship and indicate their personal facts, opinion, and experience.

3. Timely, WOM happens when someone need them and interested to a specific product.

Word of Mouth facilitate information sharing among people through communication. Story telling is a form of word of mouth communication where someone tell others a story about something real. When WOM is mediated through electronic media, it will become an electronic word of mouth (eWOM). Electronic Word of Mouth refers to any statement shared by consumer through the Internet (such as web site, social network, instant message, news feed) about a product, service, brand or company.

The Internet and social media allow eWOM to become an important part of company communication. In consumer behavior, eWOM also an important aspect related to group influence [11]. Electronic Word of Mouth can potentially affect someone's purchase intention.

Various studies use many eWOM definition such as [28] [28] [29]. This study use eWOM definition related to its quality offered in this research [28].

\section{Online Purchase Intention}

The relationship between purchase intention and purchase decision can be derived from Theory of Planned Behavior (Ajzen, 1991). Theory of Planned Behavior (Ajzen, 1991) mentioned that intention (and behavior) is a function of three antecedents namely personal attribute, social influence, and behavioral control perception. This theory is based on assumption that human will act in a rational manner. They will consider available information, and any implication from their decision.

Buyer intention to involve in a transaction is a significant predictor for actual participation in an e-commerce transaction [9]. The relationship between intention and actual behavior is caused by rational assumption, therefor intention to do (or not do) something is a direct influencer for actual behavior. 
Another model that relate purchase intention and purchase decision is offered by Kotler \& Keller. After consumers follow the steps of alternative evaluation in purchase decision process, at the end of the process they will form willingness to buy. But this intention is not transform immediately into purchase decision. There are two more intervening variables that could affect purchase decision called attitudes of others and unanticipated situational factors.

In general, intention is defined by Ajzen as "Indications of how hard people are willing to try, of how much of an effort they are planning to exert, in order to perform the behavior" [10]. Related to previous researches on online purchase in web sites, online purchase intention is defined as "Indicated customers' intentions to transact via the website for their renewal of their car insurance" [30] or "A consumer's willingness to purchase products or services from a particular web site" [31]. Other definition alternative also offered by [32] as follows "a consumers' willingness to buy a given product at a specific time or in a specific situation".

This study use [32] definition since it represent online study in a web site. This definition also views purchase intention in more generic way compared to [31].

\section{Online Purchase Decision}

Kotler \& Armstrong stated that consumer purchase decision is a step to get the most relevant brand after they consider and evaluate many options they get from previous process [6]. This decision is a relationship between purchase goal and result. Purchase goal usually based on factors like family income, price or expected benefit from a product. In many cases, purchase goal doesn't met the actual purchase and this will lead to dissatisfaction.

Some costumer worry about the risk that arise during buying process and co something to minimize those risks, like collects more information or find famous brand or product warranty. Online purchase decision is defined as "a continuous process, which refers to thoughtful, consistent action undertaken to bring about need satisfaction." [33].

\section{E. Social Networking Site}

Social networking site is a part of social media also known as Web 2.0 application. Social media is an online media where their users can easily participate, share, and create content. Blog, social network and wiki are examples of popular social media used by people around the world. Kaplan \& Henlein define social media as a group of internet based application developed based on ideology and Web 2.0 technology, and allow user-generated content creation and exchange [34].

Constantinides mentioned that social media and Web 2.0 are used interchangeably and define it as:

A collection of open-source, interactive and user-controlled online applications expanding the experiences, knowledge and market power of the users as participants in business and social processes. Web 2.0 applications support the creation of informal users' networks facilitating the flow of ideas and knowledge by allowing the efficient generation, dissemination, sharing and editing/refining of informational content [4].
Another social network site definition is a web based service that allow individuals to create public or semipublic profile in a close system, create a list of other users that have common relationship, and see and dig their contact list and what they create in the system [35]. Kotler define social media as a tools for consumers to share text, picture, voice, and video information each other and with company [27].

\section{RESULT AND DISCUSSION}

Various studies have investigated topics related to online purchase decision and eWOM. The most relevant results are shown in table 1.

TABLE I. SUMMARY OF PREVIOUS STUDIES RELATED TO ONLINE PURCHASE DECISION AND EWOM

\begin{tabular}{|l|l|}
\hline Research & \multicolumn{1}{|c|}{ Description } \\
\hline$[26]$ & $\begin{array}{l}\text { Study regarding the relationship of social capital, } \\
\text { eWOM and purchase intention in Facebook. Research } \\
\text { is conducted in a Facebook fan page }\end{array}$ \\
\hline$[29]$ & $\begin{array}{l}\text { Investigates what caused eWOM in Facebook. } \\
\text { Variable involved are tie strength, trust, normative } \\
\text { and informational influence.Meneliti apa yang } \\
\text { mempengaruhi eWOM di Facebook. }\end{array}$ \\
\hline$[36]$ & $\begin{array}{l}\text { Study about eWOM in social network. This study did } \\
\text { not investigated what caused eWOM. }\end{array}$ \\
\hline$[9]$ & $\begin{array}{l}\text { Factors that affect online purchase intention. Variable } \\
\text { involved are trust. The research is not conducted in } \\
\text { social networking site. }\end{array}$ \\
\hline$[37]$ & $\begin{array}{l}\text { This study aim to investigate the effect of eWOM to } \\
\text { purchase intention and what factor affect eWOM in a } \\
\text { social networking site }\end{array}$ \\
\hline$[5]$ & $\begin{array}{l}\text { Investigated eWOM, Trust, Flow, and purchase } \\
\text { intention. }\end{array}$ \\
\hline$[26][38]$ & $\begin{array}{l}\text { Study the relationship between eWOM, Social } \\
\text { Capital and knowledge sharing. It did not investigate } \\
\text { relationship with purchase intention or decision. }\end{array}$ \\
\hline$[39][40]$ & $\begin{array}{l}\text { Study about eWOM and selling. This research didn't } \\
\text { study the antecedents of eWOM. }\end{array}$ \\
\hline
\end{tabular}

Social capital premise believe that social network has value. Social capital theory was developed based on two approaches, capital theory [18] and Rational Choice Theory [19]. Nahapiet \& Ghoshal offer comprehensive approach that tried to combine many aspects of social capital point of views [23]. They offered three dimensions namely: structural, relational, and cognitive [24]. Moreover, Chiu et, al. Explain that important aspects from those three dimensions are Structural (Social Interaction Ties), Relational (Trust, Norms, Identification), and Cognitive (Shared Vision and Shared Language). Social capital proved to have effect on eWOM within a social network [38] [26].

Marketing management usually comprise marketing mix activities including Price Product, Promotion, and Place [27]. Promotion has eight communication modal including word of mouth marketing [27].

The Internet, especially social media makes eWOM become an important part of marketing strategy and group influence that can affect online consumer behavior [11]. Electronic WOM could affect online purchase intention [5] [37] and online purchase decision [39] [40] [41] [42]. 
Consumer decision process model consists of 5 stages including need awareness, information seeking, and evaluation of alternatives, buying decision, and post purchase behavior [11] [6] [43]. Purchase decision stage is an important ultimate step [27] because at this stage someone will actually buy something

Theory of Planned behavior explained that purchase decision affected by purchase intention [10]. In an online environment, this relationship also exists. Research showed that online purchase intention is a strong predictor of online purchase decision [9].

Online activities has change to social network activity. This fact leads to the importance of eWOM for marketer. The social network usage for marketer is increasing [11]. It is predicted that two third of online purchase decision is affected by eWOM [11]. Word-of-Mouth tend to be more credible compare to other information source that come from commercial sources like advertising and sales person [6].

Consumers also rely more and more to word-of-mouth rather than other information sources when it comes to online purchase decision [44] since opinion and personal experience is a strong indication for a potential buyer when try to evaluate product prior to purchase decision [32].

To encourage high quality eWOM in social network site, marketers need to know what drive eWOM. Researches showed that eWOM in social networking site is affected by social capital [29] [38] [26].

Based on those previous researches and analysis, this study proposed the following model exhibited in figure 1 . This model is a proposed model that relate the antecedents of eWOM called social capital and their relationship with online purchase intention and moreover to online purchase decision.

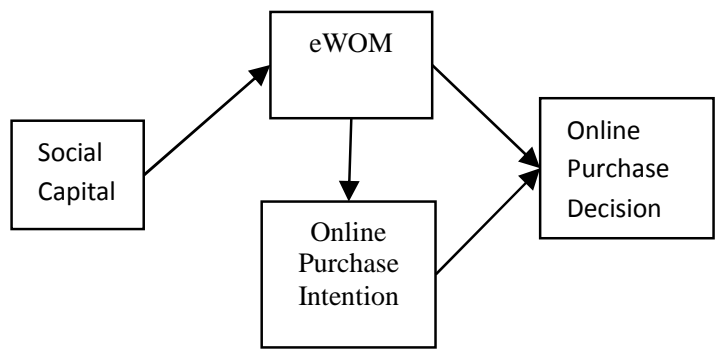

FIGURE 1 PROPOSED MODEL

This research has tried to study the cause of online purchase decision within a social networking site. Previous researches have been studied to develop a model that relate online purchase behavior and intention with eWOM, an important marketing communication mode in social networking site. Moreover, this study also propose social capital as the antecedent of eWOM. The result of this study propose a more comprehensive model for online purchase decision within a social networking site that include SOCIAL CAPITAL, EWOM, online purchase intention and online purchase decision.

\section{CONCLUSION}

A model consist of Social Capital, eWOM, Online Purchase Intention and Online Purchase Decision has been developed and proposed to relate between what trigger eWOM and Online Purchase Decision. This model was developed based on previous related research and could be useful to explain online consumer behavior within a social networking site.

\section{IMPLICATION}

The proposed model could be useful to understand what marketing stimuli that should be used to increase Social Capital in order to gain online purchase decision within social networking sites. Further study is needed to investigate the proposed model using quantitative method.

\section{REFERENCES}

[1] Chao-Min Chiu, Meng-Hsiang Hsu, Hsiangchu Lai, and Chun-Ming Chang, "Re-examining The Influence of Trust on Online Repeat Purchase Intention: The Moderating Role of Habit and Its Antecedents," Decision Support System 53, pp. 835-845, 2012.

[2] Arun Thamizhvanan and M.J. Xavier, "Determinants of Customers' Online Purchase Intention: An Empirical Study in India," Journal of Indian Business Research, pp. 17-23, 2013.

[3] Roy Morgan, "Roy Morgan Single Source Indonesia : April 2013 March 2014," 2014.

[4] Efthymios Constantinides and Stefan J Fountain, "Web 2.0: Conceptual Foundation and Marketing Issues," Journal of Direct, Data and Digital Marketing, pp. 231-244, 2008.

[5] Eric W.K. See-To and Kevin K.W. Ho, "Value co-creation and purchase intention in social network sites: The role of electronic Word-of-Mouth and trust - A theoretical analysis," Computers in Human Behavior 31, pp. 182-189, 2014.

[6] Philip Kotler and Gary Armstrong, Principles of Marketing 14/E. Upper Saddle River, New Jersey: Prentice Hall, 2012.

[7] Lloyd C. Harris and Mark M.H. Goode, "Online servicescapes, trust, and purchase intentions," Journal of Service Marketing, pp. 230-243, 2010.

[8] Katija Vojvodic and Matea Matic, "Online Purchase Intentions of Croatian Customers," Journal of Knowledge Management, Economics and Information Technology, 2012.

[9] Dan J. Kim, Donald L. Ferrin, and H. Raghav Rao, "A Trust-based Consumer Decision-making Model in Electronic Commerce: The Role of Trust, Perceived Risk, and Their Antecedents," Decision Support System, pp. 544-564, 2008.

[10] Icek Ajzen, "The Theory of Planned Behavior," Organizational Behavior and Human Decision Processes, pp. 179-211, 1991.

[11] Del I. Hawkins and David L. Mothersbaugh, Consumer Behavior: Building Marketing Strategy/12E. New York: McGraw-Hill, 2013.

[12] Robert V. Kozinets, Kristine de Valck, Andrea C. Wojniki, and Sarah J. S. Wilner, "Networked narratives: understanding word-of-mouth marketing in online communities," Journal of Marketing, pp. 71-89, 2010.

[13] J. Kietzmann and A. Canhoto, "Bittersweet! Understanding and Managing Electronic Word of Mouth," Journal of Public Affairs, pp. 146-159, 2013.

[14] Jon Swartz, Small Firms Dive Into Social Media, Juli 22, 2010.

[15] Global Indonesian Voices. (2014, Apr) http://sg.news.yahoo.com. [Online]. https://sg.news.yahoo.com/social-media-craze-indonesia053027589.html

[16] Alejandro Portes, "Social Capital: Its Origins and Applications in Modern Sociaology," Annual Reviews Sociology, pp. 1-24, 1998. 
[17] Julia Häuberer, "The Founding Concepts of Social Capital - Bourdieu's Theory of Capital and Coleman's Rational-Choice Approach to Social Capital," in Social Capital Theory: Towards a Methodological Foundation. Wiesbaden: VS Verlag für Sozialwissenschaften, 2011, pp. 35-51.

[18] Pierre Bourdieu, "The Forms of Capital," in Readings in Economic Sociology. Oxford: Blackwell Publishers Ltd, 2002, pp. 280-291.

[19] James S. Coleman, "Social Capital in the Creation of Human Capital," American Journal of Sociology, pp. S95-S120, 1988.

[20] Barry Wellman and Scot Wortley, "Different Strokes from Different Folks: Community Ties and Social Support," American Journal of Sociology, pp. 558-588, 1990.

[21] Moira Burke, Robert Kraut, and Cameron Marlow, "Social Capital on Facebook: Differentiating Ises and Users," in In Proceedings of the SIGCHI Conference on Human Factors in Computing Systems, 2011, pp. 571-580.

[22] S Valenzuela, N Park, and K F Kee, "Is There Social Capital in Social Network Site?: Facebook Use and College Student's Life Satisfaction, Trust, and Participation," Journal of Computer-Mediated Communication, vol. 14, no. 4, pp. 875-901, 2009.

[23] Paul S Adler and Seok-Woo Kwon, "Social Capital: Prospects for a New Concept," The Academy of Management Review, vol. 27, no. 1, pp. 1740, January 2002.

[24] J Nahapiet and S Ghoshal, "Social Capital, Intellectual Capital and the Organizational Advantage," Academy of Management Review, vol. 23, no. 2, pp. 242-268, 1998.

[25] C-M Chiu, M-H Hsu, and E. T. G. Wang, "Understanding Knowledge Sharing in Virtual Communities: An Integration of Social Capital and Social Cognitive Theories," Decision Support Systems, vol. 42, no. 3, pp. 1872-1888, 2006.

[26] Jae H Choi and Judy E Scott, "Electronic Word of Mouth and Knowledge Sharing on Social Network Sites: A Social Capital Perspective," Journal of Theoritical and Applied Electronic Commerce Research, vol. 8, no. 1, pp. 69-82, April 2013.

[27] Phlip Kotler and Kevin L Keller, Marketing Management 14th Edition. New Jersey: Prentice Hall, 2012.

[28] Thorsten Hennig-Thurau, Kevin P. Gwinner, Gianfanco Walsh, and Dwayne D. Gremier, "Electronic word-of-mouth via consumer-opinion platforms: What motivates consumers to articulate themselves on the Internet?," Journal of Interactive Marketing, vol. 18, no. 1, pp. 38-52, Jan 2004.

[29] Neveen F. Awad and Arik Ragowsky, "Establishing Trust in Electronic Commerce Through Online Word of Mouth: An Examination Across Genders," Journal of Management Information Systems, pp. 101-121, 2008.

[30] S-C Chu and Y Kim, "Determinants of consumer engagement in electronic word-of-mouth (eWOM) in social networking site," International Journal of Advertising, vol. 30, no. 1, pp. 47-75, 2011.
[31] Thijs Broekhuizen and Eelko K.R.E Huizingh, "Online Purchase Determinants: Is Their Effect Moderated by Direct Experience?," Management Research News, pp. 440-457, 2009.

[32] Hong-Youl $\mathrm{Ha}$ and Swinder Janda, "The effect of customized information on online purchase intentions," Internet Research, pp. 496519, 2014.

[33] Long Chuan Lu, Wen Ping Chang, and Hsiu Hua Chang, "purchase intention: The effect of sponsorship type, product type, and brand awareness," Computers in Human Behavior, pp. 258-266, 2014.

[34] Mahmud Akhter Shareef, Uma Kumar, and Vinod Kumar, "Role of Different Electronic-Commerce (EC) Quality Factors on Purchase Decision: A Developing Country Perspective," Journal of Electronic Commerce Research, vol. 9, no. 2, pp. 92-113, 2008.

[35] A M Kaplan and M Haenlein, "Users of the world, unite! The challenges and Opportunities of Social Media," Business Horizons, vol. 53, no. 1, pp. 59-68, 2010.

[36] Danah M Boyd and Nicole B Ellison, "Social network sites: Definition, history, and scholarship," Journal of Computer-Mediated Communication, vol. 13, no. 1, pp. 210-230, 2008.

[37] J. C. Sweeney, G. N. Soutar, and T. Mazzarol, "Word of mouth: Measuring the power of individual messages," European Journal of Marketing, vol. 46, no. 1, pp. 237-257, 2012.

[38] Marjan Mortazavi, Mohammad Rahim Esfidani, and Shaemi Ali Barzoki, "Influencing VSN Users' Purchase Intentions: The Roles of Flow, Trust and eWOM," Journal of Research in Interactive Marketing, vol. 8, no. 2, pp. 102-123, 2014.

[39] K. H. Hung and S. Y. Li, "The influence of eWOM on virtual consumer communities: Social capital, consumer learning and behavioral outcomes," Journal of Advertising Research, pp. 485-495, 2007.

[40] Judith Chevalier and Dina Mayzlin, "The Effect of Word of Mouth on Sales: Online Book Reviews," Journal of Marketing Research, pp. 345354, 2006.

[41] Nan Hu, Ling Liu, and Jennifer Zhang, "Do Online Reviews Affect Product Sales? The Role of Reviewer Characteristics and Temporal Effects," Information Technology and Management, pp. 201-214, 2008.

[42] Godfrey Themba and Monica Mulala, "Brand-Related eWOM and Its Effects on Purchase Decisions: An Empirical Study of University of Botswana Students," International Journal of Business and Management, 2013.

[43] Christy M.K. Cheung, Bo Sophia Xiao, and Ivy L.B. Liu, "Do actions speak louder than voices? The signaling role of social information cues in influencing consumer purchase decisions," Decision Support Systems, pp. 50-58, 2014.

[44] Leon G. Schiffman, Leslie Lazar Kanuk, and Joseph Wisenblit, Consumer Behavior 10/E. Upper Saddle River, New Jersey: Prentice Hall, 2010.

[45] Paul C.S. Wu and Yu-Chen Wang, "The Influences of Electronic Wordof-Mouth Message Appeal and Message Source Credibility on Brand Attitude," Asia Pacific Journal of Marketing and Logistic, vol. 23, no. 4, pp. 448-472, 2011. 